\title{
Kekhasan Eskatologi Paulus
}

\author{
E. Chrisna Wijaya $)^{1)^{*}}$ \\ 1) Dosen Sekolah Tinggi Teologi Internasional Harvest Semarang \\ *) Korespendensi penulis: chrisna.wijaya@yahoo.co.id
}

Received: 7 March 2018 / Revised: 9 April 2018 / Accepted: 15 May 2018

\begin{abstract}
Abstrak
"Kekhasan Eskatologi Paulus," merupakan penelitian yang memberikan eksplanatori mengenai pemikiran-pemikiran teologis Paulus, secara khusus berkaitan dengan pemikiran-pemikiran atau pengajaran mengenai akhir zaman (eskatologi). Hal tersebut mengingat bahwa eskatologi merupakah salah satu doktrin dalam teologi sistematika yang belum tergenapi sehingga seringkali menimbulkan perdebatan dan tidak jarang menjadi doktrin yang diabaikan karena kesulitan atau kekeliruan dalam menafsirkan ajaran tersebut. sehubungan dengan hal tersebut, maka penelitian ini bermaksud untuk memberikan klarifikasi dan afirmasi bahwa keyakinan Paulus akan peristiwa-peristiwa akhir zaman yang terdapat dalam pembahasan eskatologinya merupakan fakta yang benar-benar akan terjadi. Di samping itu, penelitian ini juga bermaksud untuk menyampaikan keunikan atau kekhasan doktrin akhir zaman tersebut dari perspektif rasul Paulus. Untuk mewujudkan pemahaman tersebut, maka penulis melaksanakan kajian terhadap beberapa ayat Alkitab dan pandangan para pakar dalam mengadakan pendekatan terhadap ayat-ayat eskatologi Paulus. Dari pendekatan tersebut, diperoleh beberapa pemahaman mengenai kekhasan daripada eskatologi Paulus yang pemikiran teologis yang tidak murni berasal dari dirinya sendiri, namun pemikirannya mendapat pengaruh yang cukup signifikan, di antaranya adalah latar belakangnya sebagai orang Yahudi asli, latar belakang kehidupannya yang diwarnai oleh pemikiran Yunani, dan yang terutama
\end{abstract}


adalah pengaruh pengalaman kekristenan Paulus sendiri. Kedua, kekhasan eskatologi Paulus nampak melalui pengertian parousia, yang merujuk pada pengertian kedatangan Kristus yang kedua kali, perspektif dan pengharapan Paulus yang pasti akan kedatangan Kristus yang kedua kali, serta nuansa kristologi yang sangat kental yang ditemukan dalam pemikiran eskatologinya.

Kata-kata kunci: kekhasan, eskatologi, Paulus, akhir zaman, parousia, kedatangan Tuhan kedua kali.

"The peculiarity of Paul's eschatology," is an explanatory study of Paul's theological thought, specifically relating to the ideas or teachings of the end-time (eschatology). It is remembered that eschatology is one of the doctrines in systematic theology that has not yet been fulfilled so it often leads to debate and often becomes a neglected doctrine because of the difficulty or error in interpreting the teaching. in this connection, this study intends to provide clarification and affirmation that Paul's belief in the events of the end times contained in his eschatological discussion is a fact that will really happen. In addition, this study also intends to convey the uniqueness or uniqueness of the end-time doctrine from the perspective of the apostle Paul. To realize that understanding, the author conducts a study of several Bible verses and the views of the experts in approaching the passages of Paul's eschatology. From this approach, there is some understanding of the peculiarities of Paul's eschatology whose impure theological thought is derived from himself, but his thoughts have had a significant influence, among them his background as a genuine Jew, his background of life stained by Greek thought, and that is primarily the influence of Paul's own Christian experience. Second, the peculiarity of Paul's eschatology is apparent through the notion of parousia, which refers to the notion of the second coming of Christ, the persistent perspective and hope of Paul in the second coming of Christ, and the deeply christological nuance found in his eschatological thought.

Keywords: peculiarities, eschatology, Paul, end times, parousia, the second coming of the Lord. 


\section{Pendahuluan}

Doktrin akhir zaman atau eskatologi merupakan doktrin atau ajaran mengenai peristiwa-peristiwa terakhir, yang seringkali banyak menuai pemikiran-pemikiran yang kontroversial dari banyak pakar teologi. Hal tersebut dikarenakan keberadaan dari peristiwa-peristiwa yang belum terjadi atau tergenapi, sehingga seringkali menuai anggapan dan interpretasi yang tidak tepat, bahkan salah kaprah, yang hingga kini sangat disayangkan, masih terus berkelanjutan dan menjadi polemik. Di antaranya adalah:

Pertama, peristiwa-peristiwa futuristis dalam eskatologi, seringkali memunculkan kesalapahaman maupun kekeliruan dalam penafsirannya. Hal tersebut membuat tidak sedikit orang Kristen yang enggan berkutat, bahkan tidak jarang bersikap skeptis dengan doktrin ini. Salah satunya seperti yang diungkapkan oleh Petrus Maryono dalam "Kata Pengantar" buku "Eskatologi"karangan Chris Marantika, yang berbunyi:

Eskatologi! Kesan negatif memang amat lekat dengan kata ini. Betapa sering kata ini disalahpahami. Keliru tafsir, yang berlanjut dengan sikap keliru, juga menandai jalannya sejarah kekristenan. Tidak mengherankan, jika banyak orang Kristen yang masa bodoh, bahkan antipati terhadap doktrin ini. ${ }^{1}$

Anggapan bahwa doktrin eskatologi merupakan doktrin yang tidak penting untuk dipelajari, sebagaimana yang dituliskan oleh Mangapul Sagala, dalam artikel “Akhir Zaman,”demikian:

Tidak semua orang sependapat bahwa doktrin akhir zaman penting untuk dipelajari. Ada yang menganggap bahwa doktrin ini sungguh penting, tetapi ada juga yang menganggapnya sebagai doktrin tambahan. Mereka ini mengatakan bahwa apa dan bagaimanapun pandangan kita tentang doktrin ini tidak akan mempengaruhi-mempercepat atau memperlambat- kedatangan 
Kristus. Karena itu, lebih baik membicarakan hal-hal lain yang jauh lebih penting. Tetapi bagi saya, doktrin ini sangat penting. ${ }^{2}$

Serupa dengan pernyataan tersebut, Maryono juga memberikan sikap atau posisinya terhadap pengajaran akhir zaman dengan menuliskan bahwa:

Jika Kitab Suci diselidiki, segera nyata bahwa eskatologi (pengajaran mengenai perkara-perkara terakhir) bukan saja penting, tetapi sangat sentral dalam pemikiran penulis Alkitab. Ajaran tentang pokok ini dapat ditemui dalam Perjanjian Lama, apalagi dalam Perjanjian Baru. Ada yang disampaikan dalam bentuk nubuat, lebih banyak lagi yang dinyatakan dalam penegasan langsung. Semua tokoh penting Alkitab bicara mengenai pokok ini, tak terkecuali Tuhan Yesus sendiri. Ia memakai minggu terakhir masa penjelmaan-Nya untuk membuka mata para murid mengenai kebenaran agung ini. ${ }^{3}$

Mengenai doktrin ini, William W. Menzies dan Stanley M. Horton telah lebih dahulu menegaskan keyakinannya, bahwa: "Mengapa doktrin ini, ajaran ini, begitu strategis? Antara lain, ini merupakan kunci kepada sejarah. Secara tak dapat dielakkan, kita sedang bergerak menuju akhir segala sesuatu." Tuhan Yesus berfirman: "Sesungguhnya Aku datang segera dan Aku membawa upah-Ku untuk membalaskan kepada setiap orang menurut perbuatannya. . . . Ia yang memberi kesaksian tentang semuanya ini berfirman: 'Ya, Aku datang segera!' Amin, datanglah, Tuhan Yesus!"5 Dengan mengamati beberapa pandangan dan keyakinan di atas, maka dapat disimpulkan bahwa meskipun eskatologi merupakan hal yang sulit untuk dipahami dan menimbulkan banyak keraguan,

${ }^{2}$ Mangapul Sagala, Artikel Akhir Zaman, www.sarapanpagi.org/akhir-zamanartikel-vt254.html. Minggu, 18 Juni 2006.

${ }^{3}$ Maryono,Kata Pengantar dalam Eskatologi.

${ }^{4}$ William W. Menzies dan Stanley M. Horton, Pengharapan yang Penuh Bahagia dalam Doktrin Alkitab, (Malang: Gandum Mas, 2003), 216.

${ }^{5}$ Wahyu 22:13, 20. 
namun doktrin ini tidak kalah penting dibandingkan dengan doktrindoktrin kekristenan lainnya.

Kedua, "Kekhasan Eskatologi Paulus." Mengapa Eskatologi Paulus? Sebagai penulis kitab yang terbanyak, yaitu 13 kitab (di luar Kitab Ibrani), tidak dapat disangkal bahwa pemikiran Paulus mengenai eskatologi sangat dominan dalam Alkitab Perjanjian Baru.Tentunya sebagai seorang teolog, Paulus tidak hanya mengajarkan doktrin akhir zaman. Teologi Paulus ${ }^{6}$ meliputi: Kristologi, soteriologi, anthropologi, pneumatologi, eklesiologi dan eskatologi.Eskatologi Paulus dan kekhasannya menjadi sorotan dalam penelitian ini, karena doktrin eskatologi merupakan "bagian integral dari keseluruhan teologi Paulus."7 Tom Jacobs dalam bukunya yang berjudul: "Paulus: Hidup, Karya dan Teologinya," menjelaskan bahwa:

Eskatologi bukan embel-embel pada teologi Paulus. Juga bukan warisan dari teologi Yahudi yang sedikit banyak disesuaikan dengan iman kristiani. Teologi Paulus secara hakiki bersifat eskatologis, justru karena bersifat kristologis. Sebab titik pangkal teologi Paulus - dan seluruh Gereja purba - adalah kebangkitan Kristus. Padahal kebangkitan Kristus adalah permulaan zaman terakhir. $^{8}$

C. Marvin Pate juga menambahkan, bahwa: "Eskatologi adalah pokok dari pikiran Paulus yang subur."9

Berdasarkan latar belakang penulisan yang telah diuraikan di atas, maka ada beberapa tujuan yang ingin dicapai oleh penulis dalam penelitian ini. Tujuan tersebut meliputi: Mas, 2004).

${ }^{6} \mathrm{C}$. Marvin Pate, Daftar Isi: The End of the Age has Come, (Malang: Gandum

${ }^{7}$ Petrus Maryono, Kuliah Program Doktoral: Teologi Paulus, 21 April 2004 di STTII Yogyakarta.

${ }^{8}$ Tom Jacobs, Paulus: Hidup, Karya dan Teologinya, (Yogyakarta: Kanisius, 1992), 245-46.

${ }^{9} \mathrm{C}$. Marvin Pate, The End of the Age has Come, (Malang: Gandum Mas, 2004), 246. 
Pertama, sesuai dengan judul dari penelitian ini "Kekhasan Eskatologi Paulus," maka penulis berupaya untuk mencari dan menemukan hal-hal yang khas Alkitabiah dari eskatologi Paulus. Kedua, melakukan kajian terhadap pandangan para pakar, tentang ayat-ayat Alkitab yang berbicara mengenai eskatologi Paulus, khususnya dari pandangan-pandangan teks yang menjadi rujukan, sehingga makalah ini merupakan perumusan teologis-ilmiah Paulus dan bukan asumsi pribadi penulis yang subyektif dan spekulatif.Ketiga, mengingat bahwa dalam konteks yang lain, istilah "eskatologi," tidak semata-mata berbicara mengenai akhir zaman, seperti yang dituliskan Peter Wongso dalam bukunya yang berjudul "Hermeneutika Eskatologi," bahwa:

Penggunaan kata "eskaton" bukan hanya menunjukkan kepada kedatangan Kristus yang kedua kali saja atau akhir dari dunia materi ini. Sebab penggunaan kata ini begitu luas, untuk menetapkan makna kata ini, hendaknya dengan teliti kita melihat cara penggunannya dalam perikop ayat tersebut, agar kita tidak menyamakan semua arti yang sama untuk kata ini. ${ }^{10}$

Dalam hal ini, penulis akan membatasi pembahasan makalah ini hanya pada doktrin tentang akhir zaman, tentunya dengan memperhatikan secara teliti dan akurat ayat-ayat tersebut sesuai dengan konteksnya.

\section{Metode}

Pelaksanaan daripada penelitian ini menggunakan metode penelitian kualitatif studi pustaka. Adapun subyek dari penelitian ini adalah eksplanatori mengenai "Kekhasan Eskatologi Paulus. Dalam melaksanakan penelitian ini, penulis melakukan tinjauan dan studi literatur terhadap salah satu isu teologi sistematika, secara khusus tentang

${ }^{10}$ Peter Wongso, Hermeneutika Eskatologi, (Malang: Seminari Alkitab Asia Tenggara, 2000), 2. 
eskatologi/doktrin akhir zaman Paulus, yang seringkali masih menuai perdebatan yang berkepanjangan hingga sekarang ini.

Sehubungan dengan penggunaan sumber literatur dalam penelitian ini, penulis menggunakan beberapa buku dan artikel yang secara umum dan juga secara spesifik membahas tentang surat-surat Paulus dan pandangan eskatologinya. Di antaranya adalah: (1) karya dari Louis Berkhof,Chris Marantika,William M. Menzies, dan Stanley M. Horton, serta C. Marvin Pate mengenai doktrin akhir zaman. (2) J. Wesley Brill, F.F. Bruce, Tom Jacobs, dan A. Berkeley Mickelsen, yang menuliskan tentang tafsiran dan hal-hal yang berhubungan erat dengan pandangan serta keyakinan Paulus mengenai akhir zaman. (3) artikel-artikel yang membahas tentang pandangan Paulus tentang akhir zaman yang ditulis oleh Mangapul Sagala dan May Linda Sari, dan(4) Beberapa buku dan informasi pendukung lainnya, yang berkaitan dengan subyek penelitian ini juga digunakan sebagai sumber penelitian yang penulis uraikan secara deskriptif dan selanjutnya membuat kesimpulan mengenai subyek penelitian tersebut.

Dalam pelaksanaan penelitian, penulis melakukan penyesuaian dengan penelitian yang dilaksanakan. 
Gambar 1. Proses Penelitian

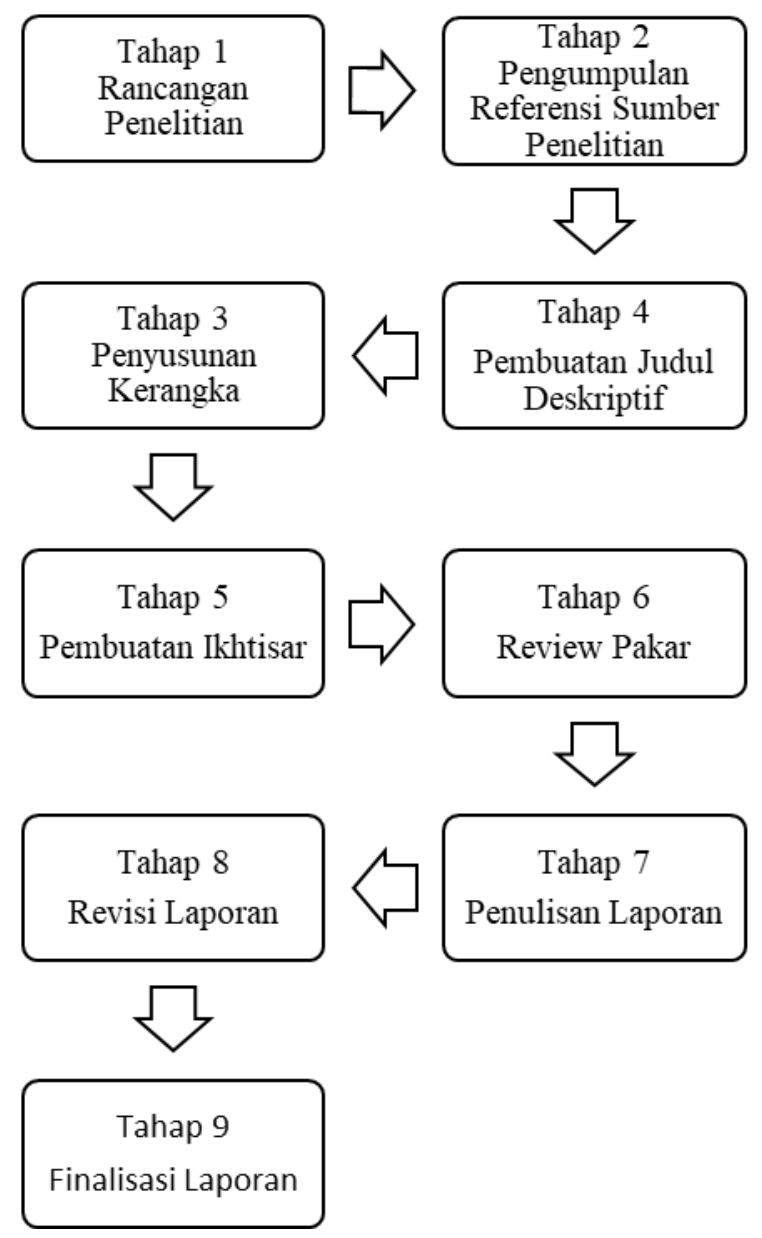

Proses penelitian ini dilaksanakan dalam 8 tahapan mulai dari tahap rancangan hingga tahap finalisasi laporan, seperti yang tertera dalam gambar 1.

\section{Hasil}

Daftar Ayat Alkitab

Hasil dari tahap pengumpulan ayat Alkitab adalah terkumpulnya ayat-ayat Alkitab yang terkait dengan topik penelitian. Adapun daftar ayat-ayat tersebut meliputi ayat-ayat yang terdapat di dalam surat-surat Paulus maupun ayat-ayat pendukung dari kitab yang ditulis oleh penulis lainnya yang berhubunganan erat dengan topik penelitian yang 
dimaksud. Ayat-ayat tersebut menjadi referensi yang dapat memberikan gambaran yang signifikan, sesuai dengan kekhasan eskatologi Paulus.

Kekhasan Eskatologi Paulus

Dalam pemaparan mengenai kekhasan eskatologi Paulus, penulis menemukan empat (4) kekhasan dalam eskatologi Paulus.Penulis dalam bagian pembahasan ini memulai dengan definisi dari eskatologi itu sendiri dan kemudian dilanjutkan dengan latar belakang pemikiran eskatologi Paulus yang selanjutnya memunculkan kekhasan eskatologi tersebut. Dengan penjelasan sebagai berikut:

Definisi

Istilah"Eskatologi," berasal dari dua akar kata Yunani. escatoj(eskhatos), yang berarti "akhir, hal-hal yang terakhir, peristiwa-peristiwa terakhir" dan $\log \mathrm{j}^{(}(\log o s)$, yaitu "kata-kata, ilmu, ajaran, doktrin, uraian." Secara harafiah dalam konteks penulisan penelitian ini, maka Eskatologi diartikan sebagai: "doktrin atau ajaran mengenai peristiwa-peristiwa terakhir/akhir zaman." Dengan demikian pembahasan mengenai kekhasan eskatologi Paulus, merujuk kepada pemikiran-pemikiran Paulus mengenai peristiwa-peristiwa di akhir zaman.

Latar Belakang Pemikiran Eskatologi Paulus

Meskipun dalam bagian sebelumnya (pendahuluan) telah dijelaskan bahwa eskatologi Paulus bukanlah merupakan warisan dari teologi Yahudi yang sedikit banyak disesuaikan dengan iman kristiani, namun tidak dapat disangkal bahwa gagasan/pemikikiran eskatologi Paulus sedikit banyak tentunya jugadipengaruhi oleh pemahaman Yahudi dan Yunani serta pengalaman pertobatan/kekristenan Paulus sendiri. Hal 
tersebut mengingat, Paulus berasal dari daerah Tarsus yang kental dengan kebudayaan Yunani, tetapi yang dididik dengan adat istiadat Yahudi yang kuat, sebagaimana yang tercermin dalam surat-surat Paulus. Sehubungan dengan hal tersebut Pate menyatakan bahwa:

Lingkungan sekular dalam zaman Paulus mencakup dua kekuatan besar yag saling berhadapan - kebudayaan Yunani dan dan pemerintahan Romawi. Berkat Aleksander Agung dan kebijakan Helenisasinya, maka kebudayaan Yunani mendominasi dunia dari tahun 331 sampai 63 sM. Sumbangan-sumbangan utamanya kepada masyarakat meliputi: menetapkan satu bahasa umum; pembauran retorika dan usaha memahami pertanyaan-pertanyaan filosofis yang diajukan oleh Sokrates, Plato, Aristoteles, dan lainlain; kesetiaan pada dewa-dewa suatu bangsa; dan penekanan pada kota atau polis, sebagai pusat integratif dari penduduk. Dalam satu atau lain cara, unsur-unsur ini berpengaruh besar bagi Paulus. . . . Paulus lahir sebagai orang Yahudi, seperti terlihat dari namanya, "Saulus" (lih. Kis. 7:58; 8:1,3, dll). Lagi pula dalam Filipi 3:5 (bdg. II Kor. 11:28), Paulus dengan bangga mengidentifikasikan dirinya sebagai "orang Ibrani asli" (mungkin merujuk kepada kemampuannya untuk berbicara bahasa Palestina). ${ }^{11}$

Selain itu, pengalaman kekristenan Paulus memegang peranan yang paling penting dalam kehidupan dan pemikiran eskatologinya, seperti yang dijelaskan F.F. Bruce dalam bukunya Paul Apostle of the Heart Set Free, mengenai perspektif baru Paulus, bahwa:

Apapun posisi Paulus sebelumnya mengenai kekekalan, hal tersebut secara tegas dimodifikasi oleh pertobatan kekristenannya. Pertobatan ini menghasilkan segera dan pasti dari visinya tentang kebangkitan Tuhan, yang memanggilnya untuk menjadi rasul-Nya. Dia yang sebelumnya telah menolak untuk mengakui - bahwa Yesus yang tersalib telah bangkit dari kematian oleh kuasa Allah, sebagaimana yang dipertahankan oleh para rasul sebelumnya sekarang ditanggungkan kepadanya dengan kesaksian yang terlalu menarik untuk diragukan. Yesus adalah Mesias itu, Anak Allah, yang sangat dimuliakan Tuhan - tetapi, yang terutama untuk

${ }^{11}$ Pate, The End of the Age has Come, 14-18. 
tujuan kita sekarang, dengan kebangkitan Yesus dari kematian yang diharapkan mulai berlangsung. ${ }^{12}$

Mengenai hal tersebut di atas, tanpa keraguan, Pate menuliskan, sebagai berikut:

Dari kesemuanya, kekristenan memainkan peranan yang paling signifikan dalam kehidupan Paulus, sebab membentuk inti batiniah dari keberadaannya. Dua pengalaman mendasar dari kerohanian Kristennya telah mengubah arah hidupnya untuk selamanya: pertobatannya kepada Yesus sebagai Mesias dan panggilannya untuk menjadi rasul kepada bangsa-bangsa bukan Yahudi. Kedua hal ini paling baik dimengerti dari perspektif eskatologi. ${ }^{13}$

Dalam upaya menegaskan pentingnya pengalaman kekristenan Paulus bagi pemikiran eskatologinya, Pate mengutip komentar Joseph A.

Fitzmeyer mengenai pokok tersebut, sebagai berikut:

Pengalaman pada jalan menuju Damaskus mengajarnya bahwa zaman Mesias telah dimulai. Ini memperkenalkan perspektif baru dalam pandangannya tentang sejarah keselamatan. Akhir zaman (eschaton) yang amat dinanti-nantikan sebelumnya, telah dimulai - meskipun tahap definitifnya belum terealisasi . . . Mesias belum datang dalam kemuliaan. Paulus menyadari bahwa ia (dengan semua orang Kristen) mendapati dirinya dalam situasi ganda: di satu situasi dia masih melihat ke belakang kepada kematian dan kebangkitan Yesus sebagai permulaan dari zaman yang baru, dan di lain situasi dia melihat ke depan kepada kedatangan-Nya dalam kemuliaan, yakni pada saat kedatangan-Nya yang kedua kali. ${ }^{14}$

Ketiga hal tersebut, yaitu: pengaruh Yunani, didikan Yahudi dan pengalaman kekristenan Paulusyang melatarbelakangi dan memberikan kontribusi pemikiran teologis yang sangat besar bagi pemikiran eskatologi Paulus. Bukan hanya memberikan kontribusi yang signifikan

${ }^{12}$ F.F. Bruce, Paul Apostle of the Heart Set Free (Michigan: Wm. B. Eerdmans, 1991), 304. [Terjemahan langsung].

${ }^{13}$ Pate, The End of the Age has Come, 21.

${ }^{14}$ Joseph A. Fitzmeyer, Pauline Theology, dalam The Jerome Biblical Commentary, peny. Raymond E. Brown, Joseph A. Fitzmeyer, dan Roland E. Murphy (Englewood Cliffs, N.J.: Prentice-Hall, 1963), 2:800-27, yang dikutip olehC. Marvin Pate, The End of the Age has Come, (Malang: Gandum Mas, 2004), 22-23. 
bagi pemikiran eskatologi Paulus, namun juga memunculkan kekhasan dalam eskatologi tersebut.

Eskatologi Paulus dan Kekhasannya

Secara spesifik, gagasan utama dari eskatologi Paulus adalah berbicara tentang "Kedatangan Kristus yang Kedua Kali." Kekhasan eskatologi Paulus nampak melalui istilah Yunani Parousia, yang mengacu pada pengertian tentang "kedatangan Kristus yang kedua kali," yang seringkali digunakan Paulus, dan yang membedakannya dari gagasan eskatologi lainnya yang terdapat dalam Perjanjian Baru.

Arti harafiah dari istilah Parousia adalah: "kehadiran, kedatangan, hadir, tiba." Paulus menggunakan istilah tersebut dalam beberapa keadaan, yaitu ketika menjelaskan kehadiran dirinya dalam 2 Korintus 10:10; Filipi 1:26, 2:12, selain itu untuk menjelaskan kehadiran rekan-rekannya dalam 1 Korintus 16:17 dan 2 Korintus 7:6-7, juga menggunakan istilah tersebut untuk menjelaskan kehadiran si pendurhaka dan kedatangan Kristus yang kedua kali, seperti yang ditulisnya dalam 2 Tesalolina 2:9; 1 Tesalonika 4:15, 5:23.

Istilah parousia menjadi khas bagi eskatologi Paulus, tidak semata-mata karena Paulus menggunakan istilah tersebut paling banyak, yaitu yang ditulis sebanyak 11 atau $14 \mathrm{kali}^{15}$ dibandingkan dengan penulis kitab lainnya. Namun terdapat beberapa faktor yang membuat istilah tersebut menjadi ciri khas dalam eskatologi Paulus.

\section{Kekhasan Pertama}

Istilah parousia sebagaimana telah dijelaskan dalam bagian sebelumnya, semata-semata tidak hanya menjelaskan atau berbicara mengenai kedatangan Kristus kedua kali. Istilah ini digunakan dalam dua

\footnotetext{
${ }^{15}$ Jacobs, Jacobs, Paulus: Hidup, Karya dan Teologinya, 250.
} 
konteks, baik konteks non teologis maupun konteks teologis yang digunakan dalam eskatologi Paulus.

Dalampenggunaan konteks non teologis (dunia Yunani), istilah parousiadigunakan untuk menjelaskan kunjungan seorang pejabat tinggi ke suatu wilayah kekuasaannya maupun kunjungan orang-orang tertentu yang dianggap penting oleh orang-orang yang dikunjunginya, contohnya seperti kedatangan rasul Paulus ke Korintus seperti yang dicatat dalam 2 Korintus 10:10.Sementara, istilah parousia dalam pengertian teologis dari konteks eskatologi, oleh Paulusdiperkenalkan kepada para pembaca surat-suratnya, untuk menunjuk kepada kedatangan Kristus sebagai Tuhan yang mulia, yaitu kedatangan-Nya kali kedua. ${ }^{16}$

\section{Kekhasan Kedua}

Kekhasan eskatologi Paulus ditinjau dari perspektif Paulus mengenai kedatangan Kristus kedua kali, yang akan terjadi tidak lama lagi pada masa Paulus hidup. Perspektif tersebut nampak dari beberapa tulisannya, seperti yang Paulus jelaskan kepada jemaat di Roma, di Tesalonika dan di Korintus, sebagai berikut:

Hal ini harus kamu lakukan, karena kamu mengetahui keadaan waktu sekarang, yaitu bahwa saatnya telah tiba bagi kamu untuk bangun dari tidur. Sebab sekarang keselamatan sudah lebih dekat bagi kita dari pada waktu kita menjadi percaya. Hari sudah jauh malam, telah hampir siang. Sebab itu marilah kita menanggalkan perbuatan-perbuatan kegelapan dan mengenakan perlengkapan senjata terang! Marilah kita hidup dengan sopan, seperti pada siang hari, jangan dalam pesta pora dan kemabukan, jangan dalam percabulan dan hawa nafsu, jangan dalam perselisihan dan iri hati. Tetapi kenakanlah Tuhan Yesus Kristus sebagai perlengkapan senjata terang dan janganlah merawat tubuhmu untuk memuaskan keinginannya. ${ }^{17}$ 
Selanjutnya kami tidak mau, saudara-saudara, bahkan kamu tidak mengetahui tentang mereka yang meninggal, supaya kamu jangan berdukacita seperti orang-orang lain yang tidak mempunyai pengharapan. Karena jikalau kita percaya, bahwa Yesus telah mati dan telah bangkit, maka kita percaya juga bahwa mereka yang telah meninggal dalam Yesus akan dikumpulkan Allah bersama-sama dengan Dia. Ini kami katakan kepadamu dengan firman Tuhan: kita yang hidup, yang masih tinggal sampai kedatangan Tuhan, sekali-kali tidak akan mendahului mereka yang telah meninggal. ${ }^{18}$

Saudara-saudara, inilah yang hendak kukatakan kepadamu, yaitu bahwa daging dan darah tidak mendapat bagian dalam Kerajaan Allah dan bahwa yang binasa tidak mendapat bagian dalam apa yang tidak binasa. Sesungguhnya aku menyatakan kepadamu suatu rahasia: kita tidak akan mati semuanya, tetapi kita semuanya akan diubah, dalam sekejap mata, pada waktu bunyi nafiri yang terakhir. Sebab nafiri akan berbunyi dan orang-orang mati akan dibangkitkan dalam keadaan yang tidak dapat binasa dan kita semua akan diubah. ${ }^{19}$

Meskipun memiliki keyakinan yang demikian terhadap waktu kedatangan Tuhan yang kedua kali, di bagian yang lain dalam tulisannya Paulus juga menambahkan dan menegaskan bahwa kedatangan Tuhan seperti pencuri pada malam hari, yang artinya tidak ada seorang pun yang tahu waktu kedatangan-Nya, sebagaimana yang dijelaskan oleh Paulus kepada jemaat di Tesalonika: "Tetapi tentang zaman dan masa, saudarasaudara, tidak perlu dituliskan kepadamu, karena kamu sendiri tahu benar-benar, bahwa hari Tuhan datang seperti pencuri pada malam." 20

Mengomentari perspektif Paulus tentang kedatangan Tuhan kedua kali yang tidak lama lagi dalam masa hidup Paulus, A. Berkeley Mickelsen, khususnya menginterpretasikan tulisan Paulus di Kitab Roma 13:11, demikian:

\footnotetext{
181 Tesalonika 4:13-15.

${ }^{19} 1$ Korintus 15:50-52.

${ }^{20} 1$ Tesalonika 5:1-2.
} 
Yang dimaksud dengan "keselamatan sudah lebih dekat bagi kita daripada waktu kita menjadi percaya" ialah segala sesuatu yang akan dilakukan Kristus bagi orang-orang percaya pada saat kedatangan-Nya yang kedua kali. Pasti Paulus berharap bahwa Kristus akan datang kembali ketika dia masih hidup. ${ }^{21}$

Pendapat yang tidak jauh berbeda diberikan oleh J. Wesley Brill, khususnya dalam menginterpretasikan 1 Korintus 15:52. Brill menyatakan bahwa:

Yang dimaksudkan Paulus dengan perkataan "kita" dalam ayat 52 ialah orang-orang percaya kepada Kristus pada waktu Tuhan Yesus datang, dan mengenai hal itu diterangkan dalam 1 Tesalonika 4:15. Paulus yakin bahwa Kristus akan kembali tetapi ia tidak tahu saatnya. Paulus juga yakin bahwa Kristus menghendaki setiap orang yang percaya kepada-Nya senantiasa menantikan kedatangan-Nya (Luk. 12:36). ${ }^{22}$

Sehubungan dengan perspektif Paulus yang demikian, penulis menyimpulkan bahwa perspektif Paulus tersebut tidak keliru atau berlebihan dalam keyakinannya. Klarifikasi dan afirmasi mengenai ketidakkeliruan dari perspektif Paulus tersebut, penulis anggap penting, mengingat bahwa ditemukan beberapa pandangan sumbang beberapa teolog terhadap perspektif Paulus tersebut. Para teologi tersebut beranggapan bahwa perspektif Paulus telah menimbulkan akibat yang fatal bagi gereja, salah satunya seperti yang dikutip oleh Jacobs dari M. Werner mengenai dampak dari penundaan parousia, demikian:

Menurut M. Werner, penundaan parousia berakibatkan pembentukan gereja. Gereja tidak lagi mengharapkan parousia, melainkan mencari tempat di dunia. Dengan kata lain menurut Werner kesadaran akan penundaan parousia, atauperubahan dalam

${ }^{21}$ A. Berkeley Mickelsen, "Roma" dalam Tafsiran Alkitab Wycliffe, peny. Charles F. Pfeiffer dan Everett F. Harrison (Malang: Gandum Mas, 2001), 3:585-86.

${ }^{22}$ J. Wesley Brill, Tafsiran Surat Korintus Pertama, peny. Bestiana S. (Bandung: Kalam Hidup, 1998), 323. 
pandangan terhadap kedatangan "hari Tuhan," mempunyai akibat yang fatal. Dengan perubahan itu berubahlah iman Kristiani. ${ }^{23}$

Meskipun demikian, dalam buku yang sama, dalam pembelaannya, Jacobs memberikan pernyataan tidak sependapat dengan Werner, dengan penjelasan sebagai berikut:

Walaupun benar bahwa Paulus pernah berkeyakinan bahwa "Tuhan sudah dekat" (Flp. 4:5), hal itu tidak pernah merupakan inti pokok Injilnya. Berdasarkan kepercayaan akan kebangkitan Kristus, Paulus merumuskan pengharapan Kristiani dalam istilahistilah yang apokaliptis. Tetapi perumusan ini selalu disadari sebagai refleksi teologis atas inti pokok Injil. Dasar pengharapan Paulus bukan apokaliptik Yahudi, melainkan iman akan karya keselamatan Allah dalam wafat dan kebangkitan Kristus. . . . Eskatologi Paulus bukan suatu ramalan apokaliptis, melainkan suatu pemahaman Injil. Maka pengharapan Paulus, kendati segala kepastian iman, tetap merupakan pengharapan. Soalnya bukan betapa lama orang harus menantikan parousia, tetapi bagaimana sikap orang terhadap parousia. Dan bukan hanya sikap terhadap parousia sebagai fakta yang akan datang, melainkan sikap iman (terhadap parousia) yang mempunyai arti dalam hidup sekarang. ${ }^{24}$

Untuk menegaskan keyakinan di atas, maka penulis juga perlu memberikan pernyataan bahwa, justru perspektif Paulus tersebut juga merupakan perspektif yang dimiliki oleh para rasul dan jemaat mulamula serta bapa-bapa gereja sebelum abad ketiga, ${ }^{25}$ meskipun pandangan mengenai kesegeraan kedatangan Kristus kali kedua tidak dinyatakan seintesif pernyataan Paulus. Senada dengan pandangan tersebut, Menzies dan Horton menjelaskan, sebagai berikut:

Orang Kristen pada abad pertama berharap Yesus akan kembali selama masa hidup mereka. Akan tetapi, seperti Rasul Paulus,

${ }^{23} \mathrm{M}$. Werner, The Formation of Christian Dogma, Adam \& Charles Black 1957 (asli: 1941), yang dikutip oleh Tom Jacobs dalam bukunya yang berjudul, Paulus: Hidup, Karya dan Teologinya (Yogyakarta: Kanisius, 1992), 266.

${ }^{24}$ Jacobs, Paulus: Hidup, Karya dan Teologinya, 266.

${ }^{25}$ Henry C. Thiessen, "Eskatologi Pribadi dan Pentingnya Kedatangan Kristus yang Kedua Kali," dalam Teologi Sistematika, peny. Vernon D. Doerksen (Malang: Gandum Mas, 1997), 525. 
mereka tidak kecewa ketika mereka menyadari bahwa hal ini tidaklah demikian, karena mereka tahu bahwa sebuah mahkota sedang menunggu (II Tim. 4:8). . . . Bagaimanapun juga, baik bagi kita untuk selalu berpikir bahwa "Yesus akan segera datang."26

Persepktif seperti itulah yang semestinya dimiliki oleh setiap orang percaya di dalam menantikan kedatangan Kristus yang kedua kali dengan berjaga-jaga, sebagai bentuk pengharapan seperti yang disaksikan oleh Paulus kepada Timotius: "Sekarang telah tersedia bagiku mahkota kebenaran yang akan dikaruniakan kepadaku oleh Tuhan, Hakim yang adil, pada hari-Nya; tetapi bukan hanya kepadaku, melainkan juga kepada semua orang yang merindukan kedatangan-Nya."27

\section{Kekhasan Ketiga}

Paulus dalam pemakaian istilah parousia, sama sekali tidak merujuk pada pengertian tentang "kedatangan Kristus yang pertama.'Istilah Parousia dipakai oleh Paulus untuk menunjukkan kepada pengertian tentang "kedatangan Kristus pada akhir zaman," atau "kedatangan Tuhan kali kedua." Penggunaan istilah parousia, yang semata-mata merujuk pada kedatangan Kristus kedua kali nampak melalui tulisan-tulisan Paulus dalam 1 Tesalonika 4:15, 5:23 dan 2 Tesalonika 2:9. Di samping istilahparousia, istilah atau ungkapan lain yang digunakan oleh Paulus sebagai cara lain untuk menjelaskan parousia, adalah apokalupsis dan epiphaneia.

Istilah apokalupsis, secara harafiah memiliki arti: "penyataan (diri) atau penyingkapan (selubung), penyibakan.” Apokalupsis memiliki pengertian: "yang menunjuk kepada penyibakan dari sesuatu yang masih

${ }^{26}$ William W. Menzies dan Stanley M. Horton, Pengharapan yang Penuh Bahagia dalam Doktrin Alkitab, (Malang: Gandum Mas, 2003), 226.

${ }^{27} 2$ Timotius 4:8. 
menghalangi kita untuk memandang Kristus, 1 Kor. 1:7; 2 Tes. 1:7 . ."28 Adapun Istilah epiphaneia, secara harafiah memiliki arti "penampakan." Epiphaneiaadalah istilah "yang menunjuk pada datangnya Kristus dari latar belakang yang tersembunyi dengan berkat keselamatan yang begitu besar." 29

\section{Kekhasan Keempat}

Pemikiran eskatologi Paulus sangat kental diwarnai dengan pemikiran kristologinya, sebagaimana yang diungkapkan oleh Jacobs, dalam tulisannya:

Yang paling khas untuk faham "parousia," Paulus ialah sifat kristologisnya. Khususnya dari 1 Tes. 4:13 dan 5:23 kelihatan bahwa bagi Paulus "parousia" bukan sesuatu yang semata-mata akan datang pada akhir zaman, melainkan sekarang sudah mulai pengaruhnya sesuai dengan seluruh pandangan eskatologis Paulus. Sebab - sebagaimana nampak dari 1 Kor. 15:23 - parousia sangat erat berhubungan dengan kebangkitan Kristus. Itulah sebabnya bahwa ia menekankan sifat pengharapan dalam menantikan "parousia." Semakin ditekankan kehadiran keselamatan Kristus (lih. Gal. 2:20; dan terutama Kol dan Ef), semakin faham "parousia" rupa-rupanya menghilang. . . .Namun yang paling penting ialah bahwa dengan segala spekulasi mengenai Kerajaan Allah itu, telah dilupakan apa yang menjadi inti gagasan Paulus, yakni bahwa "parousia" selalu dihubungkan dengan pribadi Yesus Kristus. ${ }^{30}$

Penulis memahami keberadaan tersebut sebagai hal yang wajar dan tidak mengherankan sama sekali, mengingat latar belakang pemikiran eskatologi Paulus yang telah dipaparkan dalam bagian sebelumnya. Pengalaman Kristiani Paulus, terutama perjumpaan Paulus dengan Yesus

${ }^{28}$ Louis Berkhof, "Doktrin Akhir Zaman” dalam Teologi Sistematika, pen. Yudha Thianto dan Sutjipto Subeno, peny. Hendry Ongkowidjojo, (Surabaya: Momentum, 2005), 69.

${ }^{29}$ Ibid.

${ }^{30}$ Jacobs, Paulus: Hidup, Karya dan Teologinya, 251. 
di Damaskus, memberikan kontribusi pemikiran kristologi yang sangat kuat. Dalam hal ini, Pate memberikan komentar, demikian:

Paulus mungkin tidak pernah bertemu dengan Yesus yang pernah hidup dalam sejarah, namun dia bertemu dengan Kristus yang bangkit pada jalan menuju Damaskus (I Kor. 9:1; 15:8; bdg. Kis. 9:17; 22:6-11; 26:16). Salah satu dari karakteristik penting dari penampakan itu adalah "kemuliaan" atau cahaya yang menyilaukan (Kis. 9:3; 22:6; 26:13; bdg. I Kor. 15:8 dengan 15:20-49; lih. Juga II Kor. 4:6). Kemuliaan adalah pengertian yang cukup dikenal dalam Yudaisme sebab ia digunakan untuk melukiskan tubuh kebangkitan di masa mendatang yang menantikan orang-orang percaya di dalam surga pada akhir zaman (lih. Dan. 12:2-3; I Henokh 62:15-16; II Barukh 51:3-11; IV Ezra $7: 88$, dll) ${ }^{31}$

Pemahaman yang demikian juga diteguhkan dalam tulisan Paulus kepada jemaat di Kolose yang berbunyi:

Kepada mereka Allah mau memberitahukan, betapa kaya dan mulianya rahasia itu di antara bangsa-bangsa lain, yaitu: Kristus ada di tengah-tengah kamu, Kristus yang adalah pengharapan akan kemuliaan! Dialah yang kami beritakan, apabila tiap-tiap orang kami nasihati dan tiap-tiap orang kami ajari dalam segala hikmat, untuk memimpin tiap-tiap orang kepada kesempurnaan dalam Kristus. Itulah yang kuusahakan dan kupergumulkan dengan segala tenaga sesuai dengan kuasa-Nya yang bekerja dengan kuat di dalam aku. ${ }^{32}$

Kesimpulan yang diberikan oleh May Linda Sari dalam artikelnya yang berjudul "Gagasan Eskatologi Paulus dan Maknanya bagi Jemaat pada Masa Kini," menjelaskan bahwa:

Gagasan eskatologi Paulus berfokus pada diri dan peristiwa yang melingkupi kehidupan Yesus. Jadi, suatu eskatologi yang bersifat Kristologis. Dengan gagasan utama pada peristiwa kematian dan

\footnotetext{
${ }^{31}$ Pate, The End of the Age has Come, 22.

${ }^{32}$ Kolose 1:27-29.
} 
kebangkitan Yesus, maka Paulus tampil sebagai teolog yang membangun teologi yang Kristosentris. ${ }^{33}$

Jadi, jika ada nuansa kristologi dalam eskatologi Paulus, maupun nuansa eskatologi dalam Kristologi Paulus, hal tersebut bukanlah sesuatu atau hal yang absurd. Justru hal tersebut membuat eskatologi Paulus berbeda atau memiliki kekhasan tersendiri dibandingkan dengan eskatologi penulis kitab lainnya, maupun eskatologi para Rasul lainnya. Inilah kekhasan daripada eskatologi Paulus.

\section{Kesimpulan}

Berdasarkan eksplanatori kekhasan eskatologi Paulus di atas, maka penelitian ini memperoleh beberapa kesimpulan. Kesimpulankesimpulan tersebut meliputi:

Pertama, pemikiran eskatologi Paulus merupakan pemikiran teologis yang tidak murni berasal dari dirinya sendiri. Ada beberapa pengaruh yang signifikan memberikan sumbangsih bagi pemikiran eskatologi Paulus, di antaranya adalah latar belakangnya sebagai orang Yahudi asli, latar belakang kehidupannya yang diwarnai oleh pemikiran Yunani, dan yang terutama adalah pengaruh pengalaman kekristenannya.

Kedua, adanya empat (4) kekhasan eskatologi Paulus nampak melalui pengertian dari istilah parousiayang digunakan oleh Paulus, hanya merujuk pada pengertian kedatangan Kristus yang kedua kali, serta nuansa kristologi yang sangat kental yang ditemukan dalam pemikiran eskatologinya, jika dibandingkan dengan penulis kitab lainnya.

${ }^{33}$ May Linda Sari, Artikel: Gagasan Eskatologi Paulus dan Maknanya bagi Jemaat pada Masa Kini,Sekolah Tinggi Teologi Gereja Kalimantan Evangelis. sttgke.tripod.com/id16.html 


\section{Kepustakaan}

Berkhof, Louis.2005. "Doktrin Akhir Zaman" dalam Teologi Sistematika. Diterjemahkan oleh Yudha Thianto dan Sutjipto Subeno. Disunting oleh Hendry Ongkowidjojo. Surabaya: Momentum

Brill, J. Wesley. 1998. Tafsiran Surat Korintus Pertama. Disunting oleh Bestiana S. Bandung: Kalam Hidup

Bruce, F.F. 1991. Paul Apostle of the Heart Set Free.Michigan: Wm. B. Eerdmans [Terjemahan langsung].

Jacobs, Tom. 1992. Paulus: Hidup, Karya dan Teologinya. Yogyakarta: Kanisius

Maryono, Petrus. 2007. Kata Pengantar dalam Eskatologi yang ditulis oleh Chris Marantika. Yogyakarta: Iman Press

Maryono, Petrus. 2004. Kuliah Program Doktoral: Teologi Paulus. 21 April 2004 di STTII Yogyakarta.

Menzies, William M., dan Stanley M. Horton. 2003. Pengharapan yang Penuh Bahagia dalam Doktrin Alkitab. Malang: Gandum Mas

Mickelsen, A. Berkeley. 2001. "Roma” dalam Tafsiran Alkitab Wycliffe. Disunting oleh Charles F. Pfeiffer dan Everett F. Harrison. Malang: Gandum Mas

Pate, C. Marvin. 2001. Daftar Isi: The End of the Age has Come. Malang: Gandum Mas

Sagala, Mangapul. Artikel Akhir Zaman, www.sarapanpagi.org/akhirzaman-artikel-vt254.html. Minggu, 18 Juni 2006.

Sari, May Linda. Artikel: Gagasan Eskatologi Paulus dan Maknanya bagi Jemaat pada Masa Kini. Sekolah Tinggi Teologi Gereja Kalimantan Evangelis. sttgke.tripod.com/id16.html

Thiessen, Henry C. 1997. "Eskatologi Pribadi dan Pentingnya Kedatangan Kristus yang Kedua Kali," dalam Teologi Sistematika. Disunting oleh Vernon D. Doerksen. Malang: Gandum Mas

Wongso, Peter. 2000. Hermeneutika Eskatologi. Malang: Seminari Alkitab Asia Tenggara 